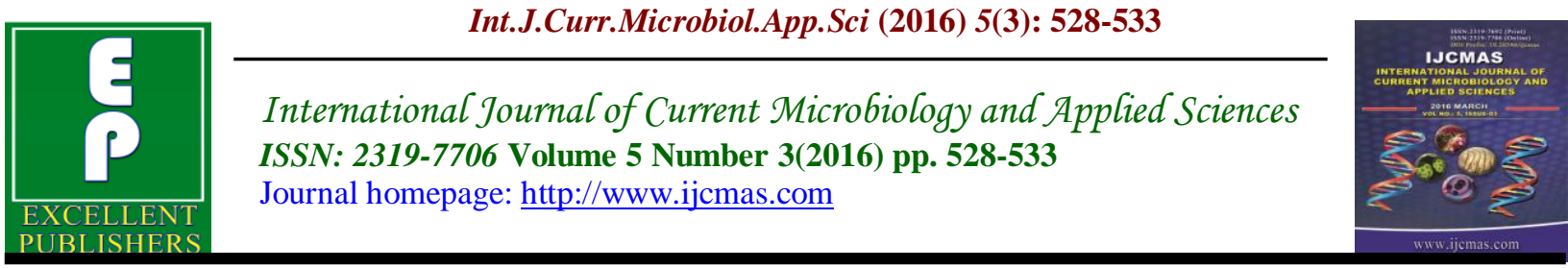

Original Research Article

http://dx.doi.org/10.20546/ijcmas.2016.503.062

\title{
Bacteriological Profile of Car Steering and Interior of Cars of Health Care Workers of a Tertiary Care Hospital
}

\author{
S. Mathavi*, G. Sasikala, A. Kavitha, A.V. Raghavendra Rao and R. IndraPriyadharsini \\ Department of Microbiology, Vinayaka Mission's Kirupananda Variyar Medical College, Salem, India \\ *Corresponding author
}

\author{
A B S T R A C T
}

Keywords

Food spills,

Footwares,

Bacillus species,

Dashboard,

Steering wheel,

Methicillin

resistant, ESBL.

Article Info

Accepted:

18 February 2016

Available Online:

10 March 2016
Studies have shown that steering wheel is actually the breeding ground for bacteria 11 times more than a public toilet. A major source of bacteria come from food spills, through air and heating vents and from footwares of passengers. The top spots for germs are dashboards, change holders, cup holders and children's car seats. The commonest organisms isolated are Bacillus species, Staphylococcus, Escherichia coli, Salmonella and Campylobacter. This study was done to know the bacteriological profile of interior of cars of health care workers. A total of 200 swabs were collected from 50 cars of health care workers of our hospitalfrom steering wheel, dashboard, cup holders and car seats. They were processed according to standard guidelines. The most common organisms isolated were Bacillus species followed by Diphtheroids, Micrococci, E.coli, Klebsiella species and Staphylococcus species. The maximum isolation was from dashboard followed by steering wheels. 32\% of Staphylococcus isolates were methicillin resistant and13\% of gram-negative isolates were ESBL producers in our study. This study concludes that cars act as potential source of contamination with many commensals and harmful microorganisms. Hence it's important to constantly clean and disinfect the car surfaces.

\section{Introduction}

The cars are the major mode of transportation for majority of people in modern world. Cars have become an indispensable part of our lives and have become a daily necessity. Studies have shown that steering wheel is actually the breeding ground for bacteria 11 times more than a public toilet. A typical steering wheel had an average of 700 kinds of bacteria compared to the 60 types found on a public toilet seat. A major source of bacteria come from food spills in various locations (Saxena et al., 2013). Microbes can also enter the vehicle through the air and heating vents. The footwares of passengers also play an important role in contamination (Saxena et al., 2013). Handling of contaminated money also introduce microbes causing infections (Mensah et al., 2002; Food Safety and Hygiene, 2000). Obviously, the areas touched with the hands harbour most germs. The top spots for germs are dashboards, change holders, cup holders and children's 
car seats (Saxena et al., 2013). While most of the bacteria are unlikely to cause health problems, some cars harbour a number of potentially harmful bacterial species. Staphylococcus and Propionibacterium are the predominant organisms. Staphylococcus spp. are found ubiquitous in the environment (Gosa Girma et al., 2014) and strains present in the nose often contaminate hands and fingers leading to skin carriers (Kumar et al., 2009)and hence the car surfaces could serve as reservoirs for pathogenic Staphylococci. They play an important role in human colonisation and infection. Another commonest organism isolated from cars is Bacillus cereus, which is an important source of food poisoning. Harmful bacteria like Escherichia coli, Salmonella and Campylobacter all of which can cause illness are also isolated. Enteric pathogens are the most frequent cause of diarrhoea and account for an annual mortality rate of about five million people worldwide (Kosek et al., 2003).Each of these has the capability to survive for as long as one month inside the car. These colonized micro-organisms may be transmitted to patients even if patients do not come in direct contact with the colonised sites (Kilic et al., 2009). These organisms if pathogenic can pose a threat to the health of the patients especially those in intensive care units. The situation worsens if the organisms are drug-resistant because of limited treatment options (Angadi et al., 2014). Multidrug-resistant (MDR) bacteria are commonly implicated in hospital acquired infections and can be challenging to eliminate (Sadat-Ali et al., 2010). It is estimated that one third of these infections can be prevented by adhering to standard infection control guidelines (Elsevier health sciences, 2011). Among health care workers, it has been reported that medical devices like thermometers, stethoscopes (Brady et al., 2006) and non-medical devices like computer, key boards (Borer et al., 2005; Bures et al., 2000), ball point pens, files, books (Ekanem et al., 1983) and mobile phone (Goldblatt et al., 2007; Sepehri et al., 2009) have an important role in the transmission and spread of microorganisms. Till now, no studies have been done to know the colonisation of interior of cars of health care personnel and their role in transmission of infection. Therefore, the present study was done to determine the possible role of cars as a reservoir of bacterial pathogens.

The aim and objectives of this study includes, to study the bacteriological profile of interior of cars of health care workers. To emphasize the importance of cleaning and disinfecting the car interiors to prevent transmission of infections. And also to emphasise the significance of proper hand washing among health care workers to prevent transmission of infections to the patients.

\section{Materials and Methods}

This cross-sectional study was done over a period of three months from June to August 2015 in Department of Microbiology, Vinayaka Mission's Kirupananda Variyar Medical College, Salem, India after obtaining institutional ethical clearance. A total of 50 cars were included in the study. Four swabs were collected from each car and a total of 200 swabs were included in the study. Swabs were collected from steering wheel, dashboard, cup holders and car seats from vehicles of health care workers of our hospital. The swabs were dipped in sterile peptone water before swabbing (Heba Sayed Selim, 2015). The swabs were then inoculated onto MacConkey agar and blood agar plates. The plates were incubated at $37^{\circ} \mathrm{C}$ for $24 \mathrm{hrs}$. Any growth on the plates were identified by colony morphology, gram staining and other 
standard biochemical reactions. The organisms were then subjected to antibiotic susceptibility tests by Kirby-Bauer disc diffusion method according to CLSI guidelines (Bauer et al., 1966). The staphylococcal isolates were tested for methicillin resistance and gram-negative bacilli were tested for ESBL production according to standard protocols (CLSI, 2014).

\section{Results and Discussion}

The most commonest organisms isolated were Bacillus species followed by Diphtheroids, Micrococci, E.coli, Klebsiella speciesandStaphylococcus species. The maximum contamination was found in dashboards (38.4\%) followed by steering wheels $(25 \%)$.

Bacillus species being ubiquitous in nature was the commonest organism isolated. Pathogenic bacteria like E.coli, Klebsiella and S.aureus were also isolated.
Dashboard was the site commonly contaminated with organisms followed by steering wheel. This could be due to frequent touching of these sites.

This study reveals that interior of cars are contaminated with microorganisms. Almost all the cars were loaded with contaminant organisms like Bacillus species and Diphtheroids. Our study also reveals the presence of many pathogenic bacteria like E.coli, Klebsiella species and S.aureus inside the cars which could be potential source of infection. The presence of drug resistant organisms also raises our concern as they cause infections with limited treatment options.

Bacillus species was isolated in $34.6 \%$ of samples in our study while in the study done by Saxena et al. (2013) it was $42.91 \%$. Once considered as non-pathogenic, Bacillus species are associated with hospital infections and can cause nosocomial infections (Karabay et al., 2007).

Table.1 Bacteriological Profile of Interior of Cars of Health Care Workers

\begin{tabular}{|c|l|c|}
\hline S.No & \multicolumn{1}{|c|}{ Organisms } & Total no of isolates \\
\hline 1. & Bacillus species & $133(34.6 \%)$ \\
\hline 2. & Diphtheroids & $97(25.2 \%)$ \\
\hline 3. & Micrococci & $76(19.7 \%)$ \\
\hline 4. & Escherichia coli & $32(8.3 \%)$ \\
\hline 5. & Staphylococcus aureus & $22(5.7 \%)$ \\
\hline 6. & Klebsiella species & $15(3.9 \%)$ \\
\hline 7. & Coagulase negative Staphylococci & $10(2.6 \%)$ \\
\hline & \multicolumn{2}{|c|}{ Total } \\
\hline
\end{tabular}

Table.2 Distribution of Isolates in Various Sites

\begin{tabular}{|c|l|c|}
\hline S.No & \multicolumn{1}{|c|}{ Site } & Total no of isolates \\
\hline 1. & Dashboard & $148(38.44 \%)$ \\
\hline 2. & Steering wheel & $96(24.94 \%)$ \\
\hline 3. & Cupholders & $79(20.52 \%)$ \\
\hline 4. & Car seats & $62(16.10 \%)$ \\
\hline
\end{tabular}


Fig.1 Drug Resistance Pattern of Staphylococcal Isolates

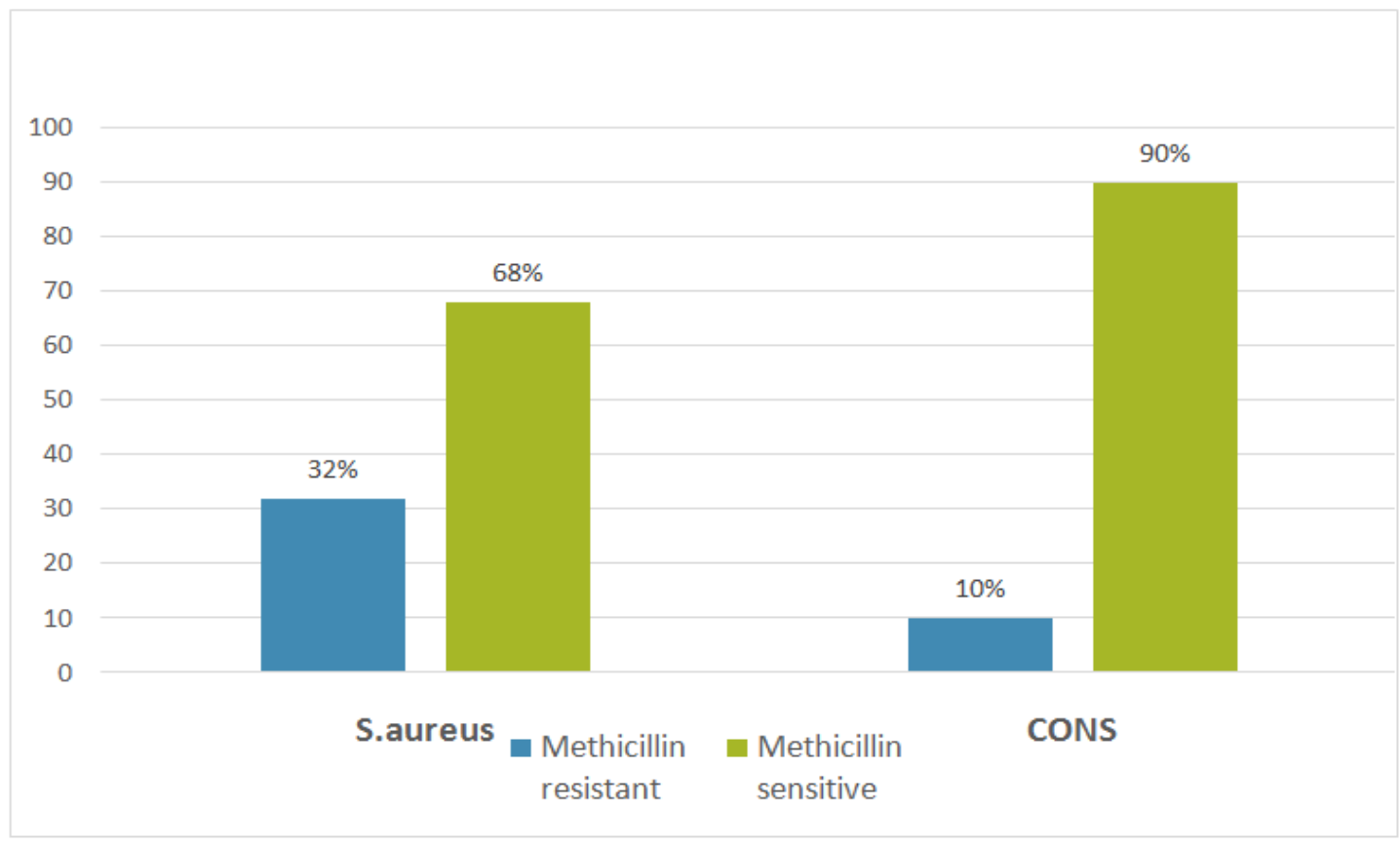

Fig.2 Drug Resistance Pattern of Gram-Negative Isolates

Non-ESBL Klebsiella, 93\%

Non-ESBL E.coli, $94 \%$

ESBL Klebsiella,

$7 \%$

ESBL E.coli, $6 \%$ 
Isolation rate of E.coli in our study was $8.3 \%$ and Klebsiella species was $3.9 \%$. This is in contrast to the study done by Saxena et al.(2013) which showed an isolation rate of $0.39 \%$ for both E.coli and Klebsiella species. S.aureus isolation rate was $5.7 \%$ in our study. This was very low when compared to isolation rate of $16.93 \%$ in the study conducted by Saxena et al. (2013). $32 \%$ of Staphylococcus isolates were methicillin resistant in our study in contrast to only $6.3 \%$ in the other study (Saxena et al., 2013). This could be because only S.aureus were isolated in that study whereas our study had both S.aureus and CONS. $13 \%$ of gram-negative isolates were ESBL producers in our study accounting for a higher incidence of drug resistant isolates.

Coming into contact with different kinds of bacteria, there's a good chance of indirectly placing them in mouth or eyes. These organisms are well documented source of respiratory infections, gastroenteritis, wound infections and urinary tract infections (Saxena et al., 2013). Of particular concern is Staphylococci especially MRSA which colonise the human skin and likely to be transmitted to inanimate surfaces in hospital environment and hence indirectly to the patients. They are capable of causing variety of nosocomial infections.

This study concludes that cars act as potential source of contamination with many commensal and harmful microorganisms. These colonized microorganisms act as source of infection both for the person travelling in it and as well as to the patients indirectly. Hence it is important to constantly clean and disinfect the car surfaces. We also emphasise on proper hand washing among the health care workers before coming in contact with the patients to prevent transmission of infections.

\section{Limitation}

In our knowledge only one study has been conducted in India to know the microorganisms of cars and hence not much references were available to compare. Hence more studies are needed to know the significance of such contamination and more research has to be done to know the effectiveness of use of disinfectants to clean the car surfaces.

\section{References}

Angadi, K.M., Misra, R., Gupta, U., Jadhav, S., Sardar, M. 2014. Study of the role of mobile phones in the transmission of Hospital acquired infections. Med. J. D.Y. Patil Univ., 7(4): 435-438.

Bauer, A.W., Kirby, W.M., Sherris, J.C., Turck, M. $1966 . \quad$ Antibiotic susceptibility testing by a standardized single disk method. Am. J. Clin. Pathol., 45(4): 493-496.

Borer, A., Gilad, J., Smolyakov, R., Eskira, S., Peled, N., Porat, N., Hyam, E., Trefler, R., Riesenberg, K., Schlaeffer, F. 2005. Cell phones and Acinetobacter transmission. Emerg. Infect. Dis., 11: 1160-1161.

Brady, R.R., Wasson, A., Stirling, L., McAllister, C., Damani, N.N. 2006. Is your phone bugged? The incidence of bacteria known to cause nosocomial infection on healthcare work's mobile phones. J. Hosp. Infect., 62: 123-125.

Bures, S., Fishbain, J.T., Uyenha, C.F.T. 2000. Computer key boards and faucet handles as reservoir of nosocomial pathogens in the intensive care units. Am. J. Infect. Control, 28: 465-470.

Clinical and Laboratory Standards Institute (CLSI) 2014. Performance standards for antimicrobial susceptibility testing; Twenty-fourth informational supplement, M100-S24. 
Ekanem, E.E., Dupot, H.L., Pickering, L.K., Selwyn, B.J., Hawkins, C.M. 1983. Transmission Dynamics of enteric bacteria in day- care centers. Am. J. Epidemiol., 118: 562-572.

Elsevier Health Sciences. 1 Jun 2011. Dangerous bacteria found on cell phones of hospital patients, Science Daily.

FSH (Food Safety and Hygiene). February 2000. A bulletin for the Australian Food Industry, Money handling in food science operations.

Goldblatt, J.G., Krief, I., Klonsky, T., Haller, D., Milioul, V., Sixsmith, D.M., Srugo, I., Potasman, I. 2007. Use of cellular telephones and transmission of pathogen by Medical Staff in New York and Israel. Infect. Control Hosp. Epidemiol., 28: 500-503.

Gosa Girma, Tsige Ketemaand Ketema Bacha. 2014. Microbial load and safety of paper currencies from some food vendors in Jimma Town, Southwest Ethiopia. BMC Res., 7: 843.

Heba Sayed Selim, Amani Farouk Abaza. 2015. Microbial contamination of mobile phones in health care setting in Alexandria, Egypt. GMS Hyg. Infect. Control, 10: Doc03.

Karabay, O., Kocoglu, E., Tahtaci, M. 2007. The role of mobile phones in the spread of bacteria associated with nosocomial infections. J. Infect. Dev. Countries, 1: 72-73.

Kilic, I.H., Ozaslan, M., Karagoz, I.D., Zer, Y., Davutoglu, V. 2009. The microbial colonisation of mobile phone used by healthcare staffs. Pak. J. Biol. Sci., 12(11): 882-884.

Kosek, M., Bern, C., Guerrant, R.L. 2003. The global burden of diarrhoeal disease, as estimated from studies published between 1992 and 2000. Bull. World Health Organ., 81: 197204.

Kumar, J.D., Negi, Y.K., Gaur, A., Khanna, D. 2009. Detection of virulence genes in Staphylococcus aureus isolated from paper currency. Int. J. Infect. Dis., 13: 450-455.

Mensah, P., Yeboah-Manu, D., OwusuDarko, K., Ablordey, A. 2002. Street foods in Accra, Ghana: how safe are they? Bull. World Health Organ., 80: 546-554.

Sadat-Ali, M., Al-Omran, A.K., Azam, Q., Bukari, H., Al-Zahrani, A.J., Al-Turki, R.A., Al-Omran, A.S. 2010. Bacterial flora on cell phones of health care providers in a teaching institution. Am. J. Infect. Control, 38(5): 404-405.

Saxena, D., Kadam, M., Kazi, M., Bhosale, M., Robert, M. 2013. Study of Microbiota Inside The Automobile Cars. Nat. J. Integrated Res. in Med., 4(1): 34-37.

Sepehri, G., Talebizadeh, N., Mirzazadeh, A., Mir-Shekari, T.R., Sepehri, E. 2009. Bacterial contamination and Resistance to commonly used Antimicrobials of Healthcare Workers mobile phones in Teaching Hospitals Kerman, Iran. Am. J. Appl. Sci., 6: 693-697.

\section{How to cite this article:}

Mathavi, S., G. Sasikala, A. Kavitha, A.V. Raghavendra Rao and IndraPriyadharsini, R. 2016. Bacteriological Profile of Car Steering and Interior of Cars of Health Care Workers of a Tertiary Care Hospital. Int.J.Curr.Microbiol.App.Sci. 5(3): 528-533. doi: http://dx.doi.org/10.20546/ijcmas.2016.503.062 